\title{
Impact of Weed Management Practices on Biomass and Grain Yield of Two Varieties of Paddy in Lowland Area of Far-Western Nepal
}

\author{
M.D. Bhatt ${ }^{1}$, S.R. Pant ${ }^{2}$ and S.P. Singh ${ }^{3}$ \\ ${ }^{I}$ Department of Botany, Siddhanath Science Campus, Mahendranagar, Nepal \\ ${ }^{2}$ Science Faculty, Nepal Academy of Science and Technology (NAST), Lalitpur, Nepal \\ ${ }^{3}$ Department of Botany, Kumaun University, Nainital - 263 002, India \\ e-mail: bhattmd@ rediffmail.com
}

\begin{abstract}
Experiments were conducted in two varieties of transplanted paddy (cv. Radha-4 and Neemai) during the rainy season of 2004-2005 in the Far-Western Terai region of Nepal to assess the effect of weed management practice. Four experiments were conducted in randomized block design with three replications viz. unweeded $\left(\mathrm{T}_{0}\right.$, weed free $(\mathrm{TT})$, manured plus twice hand-weeded after 25 and 50 days of transplanting $\left(\mathrm{T}_{1)}\right.$, and chemical fertilizer plus butachlor (weedicide) application $\left(1.5 \mathrm{~kg} \mathrm{ha}^{-1}\right)\left(\mathrm{T}_{2}\right.$. A total of 48 weed species were identified with densities of 208 ind. $\mathrm{m}^{-2}$ in Radha-4 and 196 ind. $\mathrm{m}^{-2}$ in Neemai. The mean maximum biomass of paddy in weed-free plots were 3553.6 and $3588.4 \mathrm{~g} \mathrm{~m}^{-2}$ in Radha-4 and Neemai respectively. This biomass was more or less similar to twice hand-weeded plots and herbicide treated plots being $1.3 \%$ lowering in both the varieties, compared to weed-free plots. Compared to weed-free plots, the biomass reduction in unweeded plots was recorded $26.1 \%$ lower in Radha-4 and 26.3\% in Neemai. The weed biomass was recorded highest in unweeded plots (296.9 and $236.2 \mathrm{~g} \mathrm{~m}^{-2}$ ) and lowest 155.7 and 109.1 $\mathrm{g} \mathrm{m}^{-2}$ in twice hand-weeded plots. The trend of grain yield in both the varieties were: weed free (TT) $>$ manured plus twice hand-weeded after 25 and 50 days of transplanting $\left(\mathrm{T}_{1}\right)>$ chemical fertilizer plus butachlor application (1.5 $\mathrm{kg} / \mathrm{ha})\left(\mathrm{T}_{2}\right)>$ unweeded $\left(\mathrm{T}_{0}\right)$.
\end{abstract}

Key words: rice, weeds control, Western Terai, biomass

\section{Introduction}

Paddy though is the most important crop of Nepal is mostly cultivated in traditional manner. As a result its yield is low on account of several factors, including profuse weed growth due to favorable climate condition. Weeds compete with crop plants for light, water, nutrients and space. They are self-grown which appear almost simultaneously with crop plants and therefore crop weed competition is after very intense during early stage of crop growth, which ultimately causes reduction in grain yield. Weed infestation varies from one crop to another, from one season to other, from one farm to other and even from one portion of a farm to the other (Rao 1983). Many weed species have almost identical growth and requirements as paddy therefore the cultural practices that benefit rice also help weed growth in the field (De Datta \& Baltazar 1996). They usually grow faster than the rice plant, absorb available water and nutrients earlier, establish their growth earlier and suppress crop growth and yield. The problem of weeds in transplanted paddy is extremely severe and may cause $9-51 \%$ reduction in yield (Mani et al. 1968).
The low agricultural production because of limited suitable area for cultivation is further affected by weeds, which abound along with paddy crops. There is a need to assess the loss in paddy crop production because of these unwanted and persistent weed species. Further to restrict the loss in paddy biomass it is essential to develop reliable methods by which the poor farmers can control the most common and abundant weeds. Keeping this in view, the present study was focused to examine the impact of weeds on paddy biomass and grain yield in lowland transplanted paddy growing areas of Terai region of, Far Western Nepal.

\section{Materials and Methods}

The experiments were conducted during the rainy season of 2004 and 2005 at farmers' agricultural field at Katan in Mahendranagar (28 $32^{\prime}$ N latitudes $80^{\circ} 33^{\prime}$ E longitudes, \& $185 \mathrm{~m}$ amsl). The soil was silty clay in texture with pH 6.2. Climate of the area 
is humid tropical with three distinct seasons in a year, viz. monsoon, winter and summer. Total annual rainfall during the study period was $1642.8 \mathrm{~mm}$ of which $90 \%$ was recorded during the monsoon months of the year.

The experiment was laid out in randomized block design with three replicates individual plot measured $5 \times 5 \mathrm{~m}$. The four treatments applied were: TT- weedfree, $\mathrm{T}_{0}$-unweeded, $\mathrm{T}_{1}$-manured plus twice hand-weeded after 25 and 50 days of transplanting, and $\mathrm{T}_{2}$-chemical fertilizer plus butachlor application $\left(1.5 \mathrm{~kg} \mathrm{ha}^{-1}\right)$. Twenty nine days old seedlings of paddy (viz. Radha-4 and Neemai) were transplanted in the first week of July at spacing of $20 \times 15 \mathrm{~cm}$ in the plots. The pre-emergence herbicide treatment was given three days after transplanting. A dose of N, P and $\mathrm{K}$ fertilizer was applied @ 100:30:40 kg ha-1 in TT, $\mathrm{T}_{0}$ and $\mathrm{T}_{2}$ plots respectively. Full dose of $\mathrm{P}$ and $\mathrm{K}$ and half dose of $\mathrm{N}$ were applied as the basal dose and remaining $\mathrm{N}$ was top-dressed in two equal splits at tillering and panicle initiation stage. In $\mathrm{T}_{1}$ treatments farmyard manure was applied at $15 \mathrm{tha}^{-1}$. Weed-free and unweeded treatments were kept for comparisons. The crop was harvested during the third week of October. For the estimation of weed and paddy biomass three quadrats $(30 \times 30 \mathrm{~cm})$ were randomly sampled at 25 days interval within treatments and the annual net production of weeds and paddy was calculated by summing positive increments on successive sampling dates during the study periods (Singh \& Yadava 1974). All the data were statically analyzed by using analysis of variance (ANOVA) at $\mathrm{P}$ $=0.05 \%$ significance level.

\section{Results}

A total of 48 weed species were recorded in unweeded plots of both the varieties. On the basis of importance value index (IVI) 12 major weeds in lowland transplanted paddy were; Alternanthera sessilis (L.) DC (11.3), Cynodon dactylon (L.) Pers. (10.0), Cyperus difformis, L. (11.1) Cyperus iria L. (13.0), Echinochloa colona L. Link (11.4), Echinochloa crus-galli (L.) Beauv (11.9), Eleocharis atropurpurea L. (11.7), Fimbristylis miliacea (L.) Vahl (11.7), Ischaemum rugosum Salisb (11.7), Ludwigia perennis L. (10.9), Schoenoplectus juncoides (Roxb.) Palla (11.0) and Sagittaria guayensis Kunth (10.6). Among these E. atropurpurea was late emerging weed. Among these weeds the maximum IVI was of Cyperus iria L. (13.0) and minimum of C. dactylon(L.) Pers. (10.0).

\section{Weed density}

The density of weeds was 208 ind. $\mathrm{m}^{-2}$ in Radha- 4 and 196 ind. $\mathrm{m}^{-2}$ in Neemai. The weed density was low in all the treatments than the unweeded plots. Weeds were effectively controlled by application of pre-emergence herbicide butachlor; but, this herbicide was less effective during flush and in late emerging monocot and dicot weeds. Hand weeding on $25^{\text {th }}$ and $50^{\text {th }}$ day after transplantation significantly controlled the weed growth.

\section{Weed biomass}

Weed biomass was affected due to crop weed competition in both the cultivars of paddy. The maximum total biomass of major weed species was $296.9 \mathrm{~g} \mathrm{~m}^{-2}$ in Radha-4 and $236.2 \mathrm{~g} \mathrm{~m}^{-2}$ in Neemai in unweeded plots $\left(\mathrm{T}_{0}\right)$. The lowest major weeds total biomass was 155.7 and $109.1 \mathrm{~g} \mathrm{~m}^{-2}$ in the manured and twice hand-weeded plots $\left(\mathrm{T}_{1}\right)$ of transplanted paddy Radha-4 and Neemai respectively. The butachlor plus chemical fertilizer applied plots $\left(\mathrm{T}_{2}\right)$ recorded 161.9 and $159.4 \mathrm{~g} \mathrm{~m}^{-2}$ of major weeds in Radha-4 and Neemai respectively. The major weeds biomass reduction by $47.6 \%$ in Radha-4 and $53.8 \%$ in Neemai in manured and twice hand-weeded plots, and $45.5 \%$ in Radha-4 and $32.5 \%$ in Neemai in chemical fertilizer plus butachlor used plots compared to unweeded plots. The biomass of major weed species significantly differed $(\mathrm{P}<0.001)$ from the unweeded plots in both the cultivars (Fig. 1). 
M.D. Bhatt, S.R. Pant \& S.P. Singh/Impact of Weed Management..
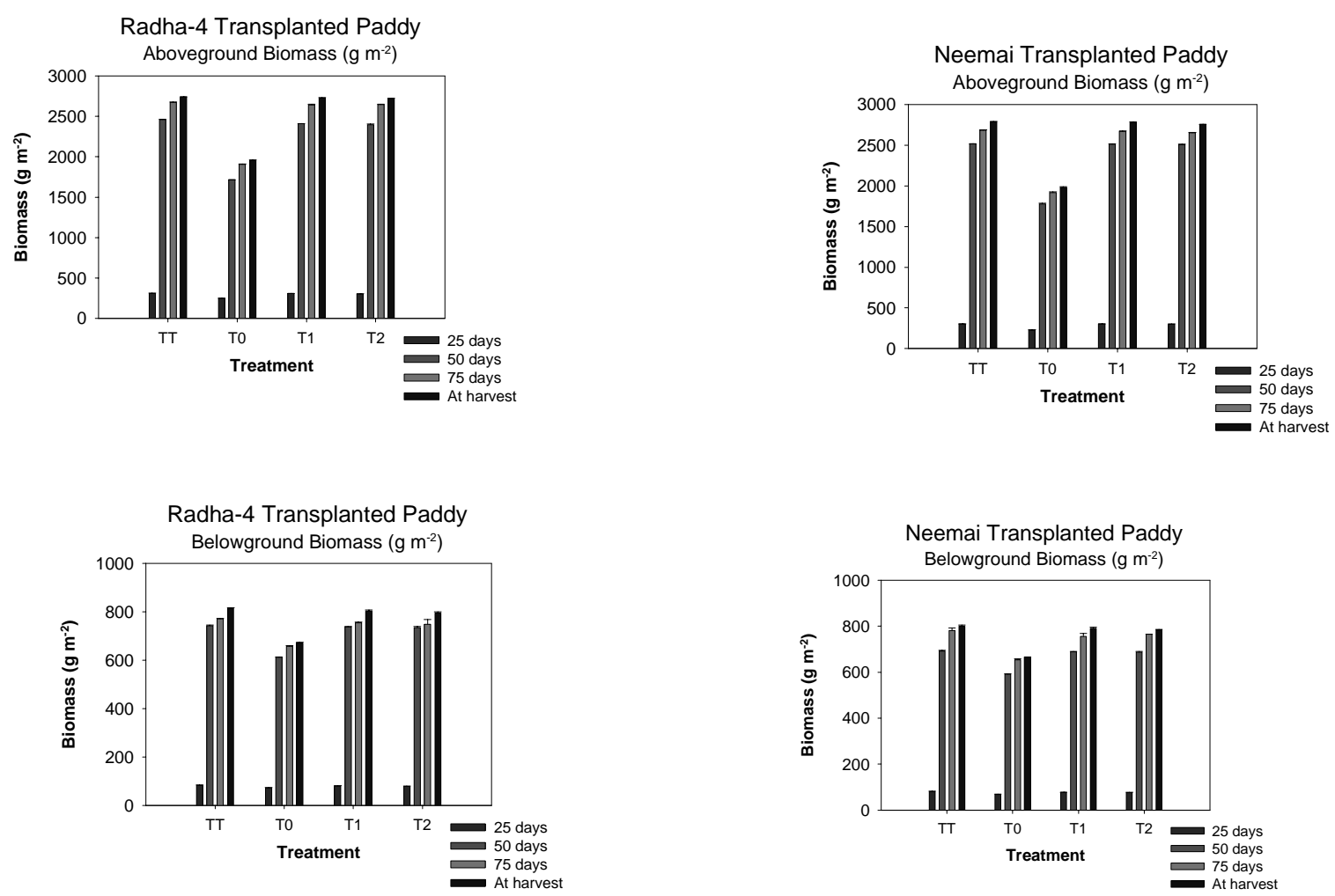

Fig. 1. Variation in aboveground and belowground biomass $\left(\mathrm{g} \mathrm{m}^{-2}\right)$ under different treatments in transplanted paddy Radha-4 and

The total net primary productivity of the major weeds was highest $273.2 \mathrm{~g} \mathrm{~m}^{-2} \mathrm{yr}^{-1}$ in Radha-4 and $216.6 \mathrm{~g} \mathrm{~m}^{-}$ ${ }^{2} \mathrm{yr}^{-1}$ in Neemai in unweeded plots $\left(\mathrm{T}_{0}\right)$, and minimum in twice hand-weeded plots $\left(\mathrm{T}_{1}\right)$ being $134.1 \mathrm{~g} \mathrm{~m}^{-2} \mathrm{yr}^{-1}$ in Radha-4 and $93.1 \mathrm{~g} \mathrm{~m}^{-2} \mathrm{yr}^{-1}$ in Neemai. The total net primary productivity reduction was $50.9 \%$ in Radha- 4 and $57.0 \%$ in Neemai in manured plus twice handweeded plots $\left(\mathrm{T}_{1}\right)$ compared to unweeded plots. In chemical fertilizer plus butachlor used plots $\left(\mathrm{T}_{-}{ }_{2}\right)$, the total net productivity was reduced by $47.7 \%$ Radha- 4 and by $28.3 \%$ in Neemai compared to unweeded plots (Table 1).

Table 1. Estimation of net aboveground, belowground and total net primary productivity $\left(\mathrm{g} \mathrm{m}^{-2} \mathrm{yr}^{-1}\right)$ by summation of all positive values of major weed species and paddy varieties in different treatments. Data are average of two years (2004-2005).

\begin{tabular}{|c|c|c|c|c|c|c|c|c|c|c|c|c|}
\hline \multirow{3}{*}{ Treatments } & \multicolumn{6}{|c|}{ Net primary productivity of major weeds in transplanted paddy } & \multicolumn{6}{|c|}{ Net primary productivity of paddy in transplanted paddy } \\
\hline & \multicolumn{2}{|c|}{$\begin{array}{l}\text { Aboveground net } \\
\text { primary productivity } \\
\text { of major weeds }\end{array}$} & \multicolumn{2}{|c|}{$\begin{array}{c}\text { Belowground net } \\
\text { primary } \\
\text { productivity of } \\
\text { major weeds }\end{array}$} & \multicolumn{2}{|c|}{$\begin{array}{l}\text { Total net primary } \\
\text { productivity of } \\
\text { major weeds }\end{array}$} & \multicolumn{2}{|c|}{$\begin{array}{l}\text { Aboveground net primary } \\
\text { productivity } \\
\text { of paddy crops }\end{array}$} & \multicolumn{2}{|c|}{$\begin{array}{c}\text { Belowground net primary } \\
\text { productivity } \\
\text { of paddy crops }\end{array}$} & \multicolumn{2}{|c|}{$\begin{array}{c}\text { Total net primary } \\
\text { productivity } \\
\text { of paddy crops }\end{array}$} \\
\hline & Radha-4 & Neemai & Radha-4 & Neemai & Radha-4 & Neemai & Radha-4 & Neemai & Radha-4 & Neemai & Radha-4 & Neemai \\
\hline Weed-free (TT) & - & - & - & - & - & $\begin{array}{l}- \\
(0.0)\end{array}$ & $\begin{array}{l}2428.68 \\
(0.0)\end{array}$ & $\begin{array}{l}2483.15 \\
(0.0)\end{array}$ & $\begin{array}{l}731.59 \\
(0.0)\end{array}$ & $\begin{array}{l}720.33 \\
(0.0)\end{array}$ & $\begin{array}{l}3160.27 \\
(0.0)\end{array}$ & 3203.48 \\
\hline Unweeded $\left(\mathrm{T}_{0}\right)$ & $\begin{array}{l}252.16 \\
(0.0)\end{array}$ & $\begin{array}{l}195.63 \\
(0.0)\end{array}$ & $\begin{array}{l}20.99 \\
(0.0)\end{array}$ & $\begin{array}{l}20.95 \\
(0.0)\end{array}$ & $\begin{array}{l}273.15 \\
(0.0)\end{array}$ & $\begin{array}{l}216.58 \\
(0.0)\end{array}$ & $\begin{array}{l}1706.24 \\
(29.75)\end{array}$ & $\begin{array}{l}1753.26 \\
(29.39)\end{array}$ & $\begin{array}{l}599.89 \\
(18.0)\end{array}$ & $\begin{array}{l}597.04 \\
(17.12)\end{array}$ & $\begin{array}{l}2306.13 \\
(27.03)\end{array}$ & $\begin{array}{l}2350.30 \\
(26.63)\end{array}$ \\
\hline anure $+\mathrm{HW}$ on & & & & & & & & & & & & \\
\hline $\begin{array}{l}25 \text { and } 50 \\
\operatorname{DAT}\left(T_{1}\right)\end{array}$ & $\begin{array}{l}121.47 \\
(51.83)\end{array}$ & $\begin{array}{l}81.18 \\
(58.50)\end{array}$ & $\begin{array}{l}12.58 \\
(40.07)\end{array}$ & $\begin{array}{l}11.94 \\
(43.01)\end{array}$ & $\begin{array}{l}134.05 \\
(50.92)\end{array}$ & $\begin{array}{l}93.12 \\
(57.0)\end{array}$ & $\begin{array}{l}2419.51 \\
(0.38)\end{array}$ & $\begin{array}{l}2475.28 \\
(0.32)\end{array}$ & $\begin{array}{l}723.12 \\
(1.16)\end{array}$ & $\begin{array}{l}713.27 \\
(0.98)\end{array}$ & $\begin{array}{l}3142.63 \\
(0.56)\end{array}$ & $\begin{array}{l}3188.55 \\
(0.47)\end{array}$ \\
\hline $\begin{array}{l}\text { Chemicalfertilizer + } \\
\text { butachlor }\left(T_{2}\right)\end{array}$ & $\begin{array}{l}125.17 \\
(50.36)\end{array}$ & $\begin{array}{l}137.85 \\
(29.54)\end{array}$ & $\begin{array}{l}17.79 \\
(15.25)\end{array}$ & $\begin{array}{l}17.53 \\
(16.32)\end{array}$ & $\begin{array}{l}142.96 \\
(47.66)\end{array}$ & $\begin{array}{l}155.38 \\
(28.26)\end{array}$ & $\begin{array}{l}2417.67 \\
(0.45)\end{array}$ & $\begin{array}{l}2457.40 \\
(1.04)\end{array}$ & $\begin{array}{l}716.81 \\
(2.02)\end{array}$ & $\begin{array}{l}707.12 \\
(1.83)\end{array}$ & $\begin{array}{l}3134.47 \\
(0.82)\end{array}$ & $\begin{array}{l}3164.52 \\
(1.22)\end{array}$ \\
\hline
\end{tabular}

$\mathrm{HW}=$ hand weeding, $\mathrm{DAT}=$ days after transplanted. Figures in the parentheses indicate percentage reduction in net primary productivity 


\section{Crop biomass}

The maximum biomass (aboveground \& belowground) was highest recorded at the time of harvest in both the paddy varieties. The maximum total crop biomass was observed in weed-free (TT) plots at lowland transplanted paddy, being $3553.6 \mathrm{~g}$ $\mathrm{m}^{-2}$ for Radha-4 and $3588.4 \mathrm{~g} \mathrm{~m}^{-2}$ in Neemai. The minimum total crop biomass for transplanted paddy was 2627.6 and $2645.7 \mathrm{~g} \mathrm{~m}^{-2}$ in unweeded plots $\left(\mathrm{T}_{0}\right)$ of Radha-4 and Neemai respectively. In twice handweeded plus manured plots $\left(\mathrm{T}_{1}\right)$ recorded 3529.5 and $3568.2 \mathrm{~g} \mathrm{~m}^{-2}$ for Radha-4 and Neemai respectively.
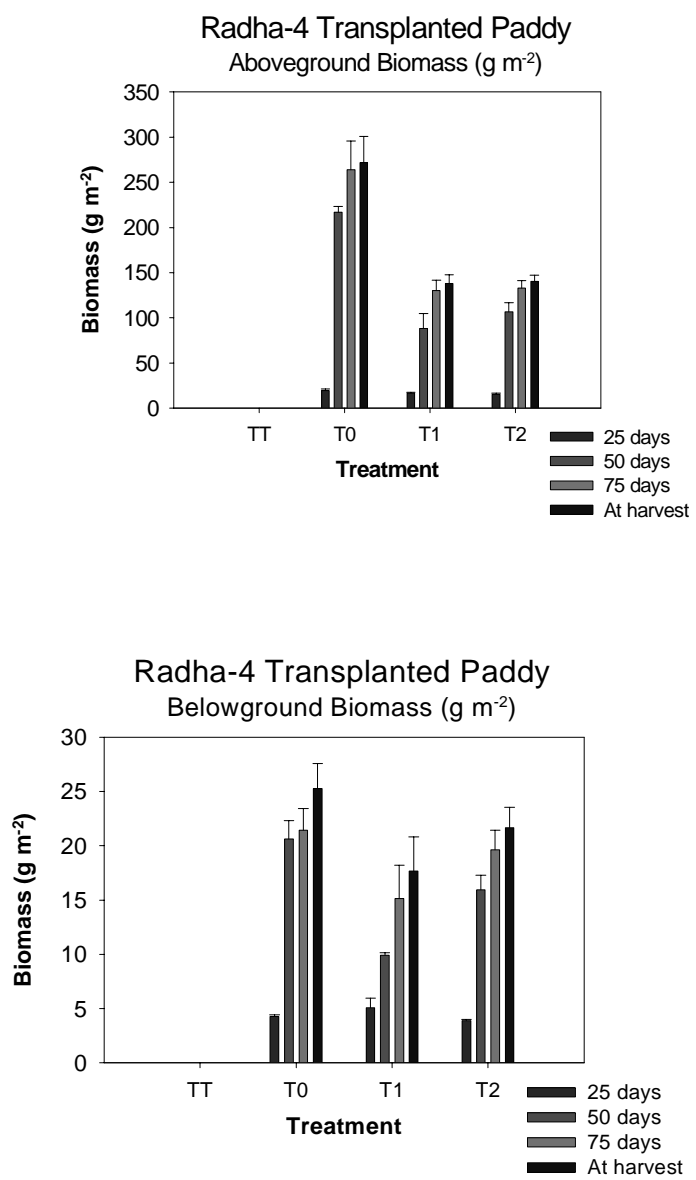

The butachlor plus chemical fertilizer applied plots $\left(\mathrm{T}_{2}\right)$ recorded 3520.1 and $3541.0 \mathrm{~g} \mathrm{~m}^{-2}$ for Radha4 and Neemai, paddy verities respectively. The difference in crop biomass between unweeded and weed-free treatments was about $26 \%$ for both varieties. In comparison to weed-free conditions the crop biomass in manured plus twice handweeded plots $\left(\mathrm{T}_{1}\right)$ was more or less similar and just $0.7 \%$ lower in Radha-4 and $1.3 \%$ in Neemai. The biomass of paddy crop was significantly different $(\mathrm{P}<0.001)$ from the weed-free plots in both the varieties (Fig. 2).
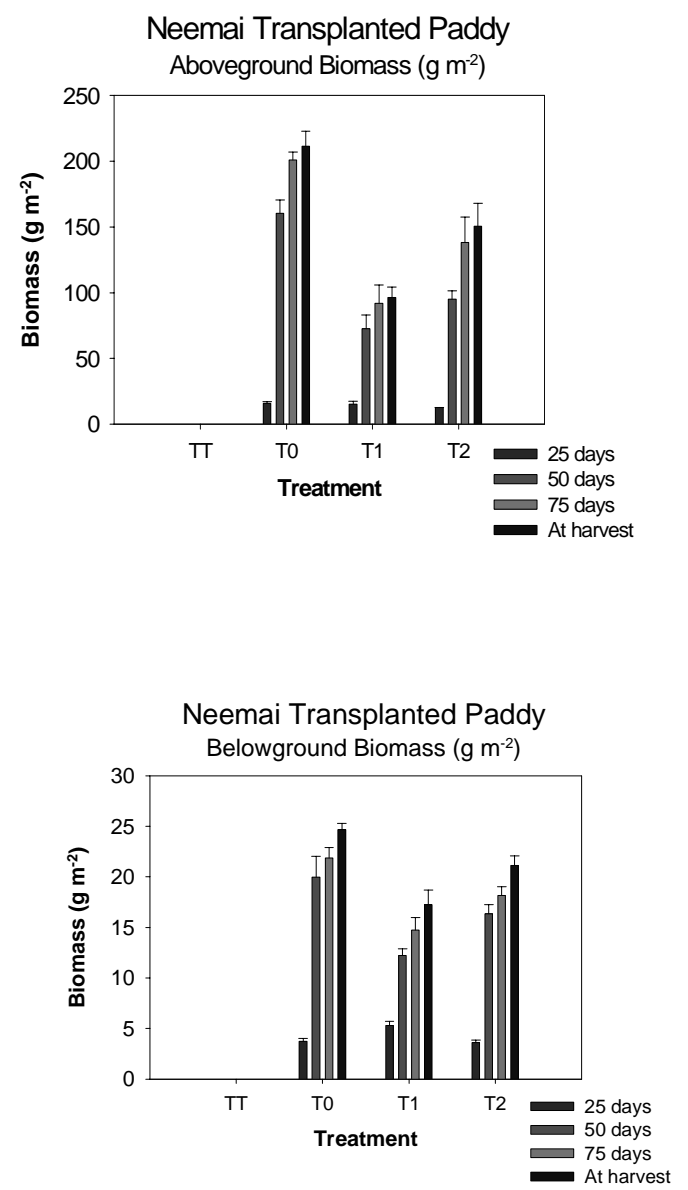

Fig. 2 Variation in aboveground and belowground biomass $\left(\mathrm{g} \mathrm{m}^{-2}\right)$ under different treatments of major weeds in transplanted paddy Radha-4 and Neemai 
The total net primary productivity of transplanted paddy was highest in weed-free (TT) plots being 3160.3 $\mathrm{g} \mathrm{m}^{-2} \mathrm{yr}^{-1}$ for Radha-4 and $3203.5 \mathrm{~g} \mathrm{~m}^{-2} \mathrm{yr}^{-1}$ for Neemai, and minimum in unweeded plots $\left(\mathrm{T}_{0}\right)$ being $3142.6 \mathrm{~g}$ $\mathrm{m}^{-2} \mathrm{yr}^{-1}$ for Radha-4 and $3188.6 \mathrm{~g} \mathrm{~m}^{-2} \mathrm{yr}^{-1}$ for Neemai. The total net primary production reduced by $27 \%$ in Radha-4 and 26.6\% in Neemai in unweeded plots compared to weed-free plots. The total net primary productivity reduced by $0.6 \%$ in Radha- 4 and $0.5 \%$ in Neemai in manured plus twice hand-weeded plots $\left(\mathrm{T}_{1}\right)$ and $0.8 \%$ in Radha-4 and $1.2 \%$ in Neemai in chemical fertilizer plus butachlor used plots $\left(\mathrm{T}_{2}\right)$ compared to weed-free plots (Table 1).

\section{Grain yield}

The maximum grain yield in Radha- 4 and Neemai was in weed-free (TT) plots 55.5 and $47.8 \mathrm{q} \mathrm{ha}^{-1}$ compared to 32.9 and $32.7 \mathrm{q} \mathrm{ha}^{-1}$ in unweeded plots $\left(\mathrm{T}_{0}\right)$, grain loss being $40.7 \%$ and $31.7 \%$ because of weeds in Radha4 and Neemai varieties, respectively. Compared to weed-free plots the grain yield was $1.5 \%$ lower in twice hand-weeded plots $\left(\mathrm{T}_{1}\right)$ in both varieties and $3.9 \%$ and $4.1 \%$ in herbicide treated plots $\left(\mathrm{T}_{2}\right)$ in Radha- 4 and Neemai. The effect of manual weeding and herbicidal treatment significantly $(\mathrm{P}<0.001)$ increased the grain yield compared to unweeded plots of both varieties.

\section{Discussion}

In the lowland transplanted areas of Terai region of FarWestern Nepal, the highest biomass of weeds caused serious crop loss upto 31.7-40.7\% and lowest biomass of weeds reduced the crop loss upto $1.5 \%$ grain yield in both the varieties of paddy. The weed density and dry matter increased with advancement in the paddy crop age. The density of weeds was maximum in Radha- 4 as compared to Neemai. The weed density was low in all the treatments than the unweeded plots.

The highest biomass of weeds was in unweeded plots in both the varieties of paddy. The lowest dry biomass was in twice hand-weeded plots in both varieties. The highest dry biomass of weeds was in unweeded plots was due to unchecked growth in this treatment where weeds continued to grow freely and accumulated highest dry matter. In both early and late weeds removed by twice hand-weeded plots at 25 and 50 days after transplanted the dry biomass of weeds decreased drastically. The loss in biomass of weeds under weed controlled agreements with the findings of Pandey and Singh (1981), Thapa and Jha (2003), Rao and Singh (1997). The application of pre-emergence herbicide alone was less effective in reduction of weed biomass since it failed to control the late emerging monocotyledonous and dicotyledonous weeds. The unweeded plots registered higher overall annual net primary productivity of weeds compared to weed-free plots and minimum in twice hand-weeded plots and followed by chemical fertilizer plus butachlor used plots.

The dry matter accumulation was consistent with variation under different treatments with respect to time. Generally dry matter accumulation increased with increase in paddy crop age and reached maximum at the time of harvest. Paddy crop biomass was significantly $(\mathrm{P}<0.001)$ affected due to weed management practices at all the stages. The highest paddy biomass was in weed-free plots of both the varieties due to no competition with weeds for nutrients, and increased availability of light, water and space. The lowest paddy crop biomass in unweeded plots was due to severe weed competition in all the stage of growth. The increased in dry matter accumulation under weed management was possibly due to relatively higher value of leaf area index resulting in more accumulation of photosynthesize and consequently the production of higher quantum of total dry matter (Rao et al. 1993, Kumar \& Rao 1993). The weed-free plots recorded highest annual net primary productivity of paddy crops and lowest in unweeded plots. Twice hand-weeded plots reduced the annual net primary productivity $0.6 \%$ in Radha- 4 and $0.5 \%$ in Neemai and butachlor treated plots $0.8 \%$ in Radha- 4 and $1.2 \%$ in Neemai compared to weed-free plots.

From the present investigation it can concluded that the yield of paddy were better in twice hand-weeded plots than in butachlor alone used plots. Radha- 4 showed better response to different weed control treatments than Neemai, and its grain yield was also higher in Terai region of Far-western Nepal.

\section{Acknowledgement}

The authors are thankful to the Mr. D. D. Joshi Campus Chief, Siddhanath Science Campus (T.U.), Mahendranagar for providing necessary facilities. The first author thanks University Grants Commission, Kathmandu Nepal for providing research fellowship and Institute of Science and Technology Tribhuvan University for granting study leave. 


\section{References}

De Datta, S.K. and A.M. Baltazar. 1996. Weed control technology as a component of rice production systems. In: Weed management in rice (Eds. B.A. Auld \& K.U. Kim), FAO, Plant Protection and Production Paper 139:25-47.

Kumar, P. and V.N. Rao. 1993. Effects of different herbicides on weed control in lowland rice. Indian J. Weed Sci. 25(2,3): 104-105.

Mani, V.S., K.C. Gautam and T.K. Chakraberty. 1968. Losses in crop yield in India due to weed growth. PANS 42: 142-158.

Pandey, J. and B.P. Singh. 1981. Effect of pre-emergence applied herbicide on micronutrients removal by lowland rice and associated in calcareous soil. Pesticides 15(11): 32-34.
Rao, A.S. and R.P. Singh. 1997. Effect of herbicide mixture and sequential application on weed control in transplanted rice (Oryza sativa). Indian J. Agron. 42(1): 77-81.

Rao, K. Venkata, R.P. Gopala and R. K. Rama. 1993. Weed control techniques in transplanted rice (Oryza sativa). Indian J. Agron. 38(3): 474-475.

Rao, V.S. 1983. Principals of weed science. Oxford and IBH Publishing Company Pvt. Ltd., New Delhi, India.

Singh, J.S. and P.S. Yadava. 1974. Seasonal variation in composition, plant biomass and net primary productivity of tropical grassland at Kurukshtra, India, Ecological Monographs 44:351-376.

Thapa, C.B. and P.K. Jha 2003. Effects of herbicides and manual weeding on the yield of transplanted paddy in Pokhara, Nepal. Ecoprint 10(1): 35-41. 